\title{
Environmental Policy Instruments and Eco-innovation
}

\author{
Meng Liu \\ $\mathrm{PhD}$ Student \\ School of Economics \\ Central University of Finance and Economics \\ 39 South College Rd., Beijing 10081, China.
}

\begin{abstract}
Global warming continues to play a significant role in affecting environment including the economy, the nature, agriculture, energy, land and water resources, transportation, and human health. Countries have adopted various types of environmental policies to prevent climate problems from continuing to deteriorate by promoting eco-technical innovation. Many studies have analyzed and tested the impact of different policies on ecological innovation. By reviewing the existing literature, this paper summarized the incentive effects of past research on the ecological innovation of command-and-control, market-based and voluntary environmental policies, and pointing out the current research trends and the direction that may be needed in the future.
\end{abstract}

Keywords: Environmental policy, Eco-innovation, Market-based policy, Command-and-control policy, Voluntary approaches

\section{Introduction}

The long-term warming trend continues in 2018, obvious signs of climate change continue to emerge, including rising sea levels, ocean warming and acidification, and melting sea ice and glaciers. According to the World Meteorological Organization (WMO), the 20 hottest years have been recorded in the past 22 years. The report shows that the global average temperature in the ten months of 2018 is nearly $1{ }^{\circ} \mathrm{C}$ higher than that capering with the pre-industrial baseline (1850-1900). Climate change is affecting the environment, agriculture, energy, land and water resources, transportation, and human health and well-being, and therefore it may lead to increased loss of infrastructure and property in the United States and hinder its economic growth rate this century.

In order to prevent the climate problem from continuing to deteriorate, countries have adopted various types of environmental policies to stimulate ecological technology innovation. In 2002, 81\% of R\&D investment came from OECD countries, while developing countries such as China only had 6\%. Developed countries were also the main source of eco-technical innovation. By 2015, on one hand the proportion of R\&D investment in OECD countries fell to $65 \%$, and China increased to $21 \%$ on the other hand. Developing countries have played an increasingly important role in promoting ecological innovation. As can be seen from Figure 1, the number of environmental protection regulations issued by the Chinese government has been growing rapidly year by year, reaching its peak in 2010 and has remained at a high order of magnitude. At the same time, the number of patent applications for ecological energy such as wind energy and solar energy in China also showed explosive growth. This paper summarizes the research on the role of different environmental policies in ecological technology innovation in developed and developing countries, pointing out the current research trends and the direction in the future.

Figure 1. Number of environmental protection policies issued by China since 1995 and the number of related patent applications

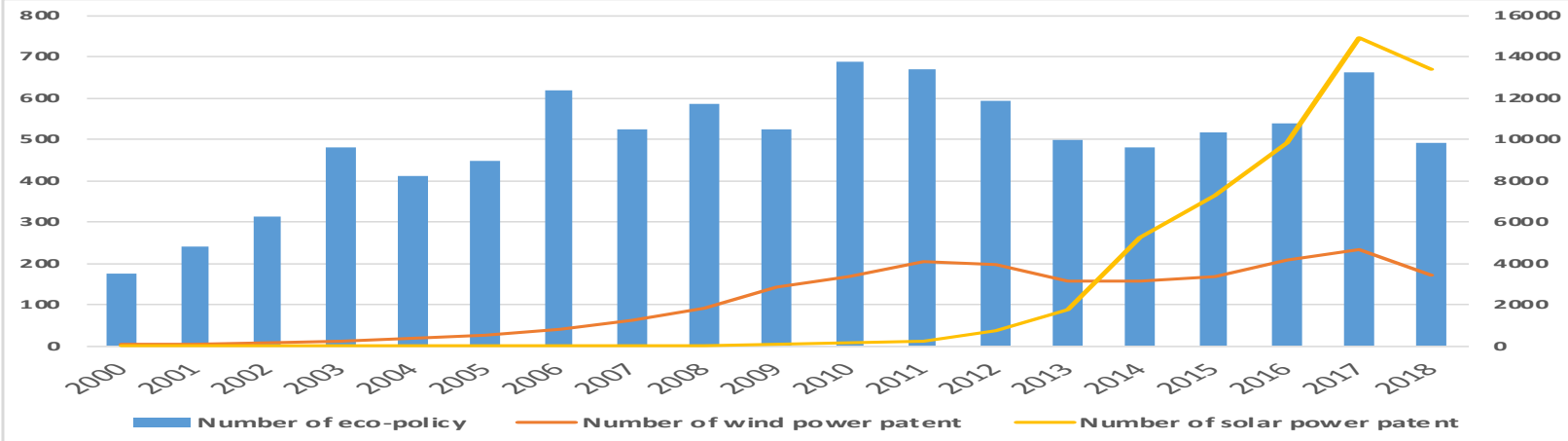

Source : NDRC,CNIPA 


\section{The main contents of China's environmental policy}

Environmental policy is the national policy of protecting the environment. It helps to solve the negative externalities caused by economic activities, and promotes important methods for enterprises and organizations to develop, apply and disseminate environmentally friendly technologies and products. The environmental policy tool refers to the general term for the various methods and technologies used by the government to achieve its environmental policy objectives. In reality, there are many types of environmental policy tools used by governments to improve the environment and pursue eco-economic development. From the perspective of management and control methods, there are several categories generally:

1.Command-and-control tools. Command-controlled environmental regulation refers to laws, regulations and policies on environmental protection formulated by government departments or environmental protection agencies. There is no doubt that mandatory is its main feature. By founding legal standards related to environmental technology, environmental performance and ecological outcomes, this method emphasized the government achieves environmental goals through imposing legal obligations or prohibitions on market entities. For example, the government would release the economic or administrative penalties for polluters who fail to obey or meet environmental requirements.

2.Market-based tools. It refers to the use of market-based means such as price and expense to reduce the level of environmental pollution throughout stimulating corporate ecological technology innovation by government. The characteristics of this method is marketability mainly. This type of method primarily reduce emissions of environmentally hazardous substances by affecting product prices or production costs to achieve environmental goals.

Market-based tools mainly include ecological taxes (environmental discharge fees and environmental taxes), subsidies, tradable emission permits, and deposit repayment schemes (environmental damage liability and compensation) etc. Such tools directly change the investment and return of market entities by changing the relative price, input cost or production cost of products that affect the environment. Such tools often positively influence ecological innovation behavior throughout providing some freedom and flexibility to polluters.

3. Voluntary tools. Voluntary conscious environmental regulation refers to the commitment or action of enterprises and residents to participate to save resources and protect the environment. The main characteristic of this method is voluntary. Voluntary conscious environmental regulation takes corporate environmental awareness as the main form of expression, as well as constrained and influenced by economic interests and corporate managers' awareness. A cooperative approach is usually used within this method to increase flexibility throughout the self-regulation of polluting entities, including negotiating agreements between government and production organizations to achieve environmental goals, as well as environmental management system certification, information labeling instructions (such as various indications of specific product environments) and etc. Voluntary tools are designed to promote environmental friendly behavior, but not mandatory and do not provide financial support.

\section{The connotation of ecological technology innovation}

The Eco-technical innovation is often called environmental technology innovation, and green technology innovation, etc. Kemp and Pearson (2007) defined it as a novel model adopted by a company or organization, so that its production process, mining methods, services, and management methods can be compared with the models it replaces. Kemp and Pearson ( 2007 ) defined that it can better reduce the environmental risks generated by the company or organization throughout its lifecycle as well as reduce pollutant emissions and other negative environmental impacts. In addition, some domestic and foreign scholars have explained on the concept of eco-technical innovation from different angles (Table 2). In summary, the core purpose of eco-technical innovation is to reduce the adverse effects of economic activities on the environment. 
Figure 2. Definition of the ecological technology innovation by scholars and institutions

\begin{tabular}{|l|l|}
\hline Scholars & Definitions \\
\hline Fussler and James(1996) & $\begin{array}{l}\text { New products, services, and processes which significantly decrease } \\
\text { environmental impacts }\end{array}$ \\
\hline Rennings(2000) & $\begin{array}{l}\text { Eco-innovations are measures of relevant elements (such as firms, } \\
\text { politicians, unions, associations, churches, private households) which } \\
\text { develop new ideas, behavior, products and processes, apply or } \\
\text { introduce them, and which contribute to a reduction of environmental } \\
\text { burdens or to ecologically specified sustainability targets. }\end{array}$ \\
\hline Kemp and Pearson (2007) & $\begin{array}{l}\text { The production, assimilation or exploitation of a product, production } \\
\text { process, service or management or business methods that is novel to } \\
\text { the firm (or organization) and which results, throughout its life cycle, } \\
\text { in a reduction of environmental risk, pollution and other negative } \\
\text { impacts of resources use (including energy use) compared to relevant } \\
\text { alternatives }\end{array}$ \\
\hline NieHongguang (2012) & $\begin{array}{l}\text { Reduces environmental hazards by using fewer resources, less toxic } \\
\text { materials; reducing the use of fossil fuels to reduce environmental } \\
\text { pollution by conducting special processes and methods. }\end{array}$ \\
\hline Yang Yan (2013) & $\begin{array}{l}\text { It is a common carrier of environmental benefits and economic } \\
\text { benefits, and thereby relies on environmental policies and social } \\
\text { progress. }\end{array}$ \\
\hline
\end{tabular}

Source: Authors

\section{IV.The impact of environmental policies on ecological technology innovation}

\section{The necessity of environmental regulation}

Due to market failures, it is impossible to rely on the market to stimulate and achieve the socially optimal level of ecological technology research and development. The environment regulations that release by the government therefore appeared to be significant. Environmental policy mainly needs to overcome three types of market failures: initially, the externality of environmental pollution. Since there is no pricing for "pollution" itself within the market, companies have no incentive to reduce pollutant emissions, therefore they have no invested in eco-technical innovation. Environmental policies could enable companies to generate emission reduction pressures by pricing emissions, which could help to stimulate eco-technical innovation.

The second is knowledge market failure. The result of innovation embodied in certain knowledge, and the public goods nature and spillover effects of knowledge are likely to cause "free riders". Such above phenomenon leads to the economic benefits of innovation not fully realized by the innovators, which is also another reason of the lacking of incentive to carry out socially optimal research and development activities. Another problem with the failure of technology markets is the path-dependent effect of technological innovation. When a company has invested heavily in a certain type of technology, the high cost of conversions makes it difficult to switch to another type of technology only by the market force (Lehmann and Söderholm, 2018). For eco-technical innovation, the market failure may result in the failure of promoting the company's research and development from "pollution" type to "clean" type. An empirical research on the US auto industry found that companies with large "pollution" type technology would "lock" to "pollution" technological innovations if there were not sufficient environmental policy impact (Aghion et al.2016). However, this study also conducted that throughout carbon taxes or the R\&D subsidy policy, the R\&D direction of these companies could change to the "clean" technology investment.

The third type of market failure is the failure of financial markets. Generally eco-technical innovations possesses the characteristics of large investment, low profitability, and high uncertainty. As a result, the financial market shows limited interest in eco-technical innovation. In conclusion, the market failure causes the problem that the market mechanism can hardly complete the optimal allocation of ecological technology innovation. It requires the government to regulate and coordinate with the forces outside the market by using environmental policies.

\section{Metrics for green technology innovation}

It is hardly to observe the innovation activities directly. Instead, three types of indicators can be used to measure the degree of innovation, which are R\&D investments, patent data and questionnaires: 


\subsection{R\&D investments}

The Previous research has difficulties to excess the micro-level data within the enterprise. Therefore some studies used R\&D investment as an indicator of innovation to test the impact of environmental policies on innovation activities instead. Jaffe and Palmer (1997) used empirical R\&D data from industry-based companies finding that the increase in emission reduction costs caused by environmental policies will increase the investment in R\&D activities, which is each $1 \%$ increase in emission reduction costs will results in $0.15 \%$ of $R \& D$ investment increase. However, although R\&D data can intuitively show the impact of environmental policies on innovation activities, there are two main problems. Firstly, R\&D data is an input to innovation activities and does not reflect the results and outputs of innovation activities. In addition, most R\&D data cannot be subdivided into the technology fields that are invested, so it is difficult to target innovative activities related to green technologies.

\subsection{Patent data}

Patents can be seen as outputs of innovation activities and are usually related to R\&D investment closely (Popp, 2010) and are therefore often used as indicators for measuring technological innovation. Moreover, comparing with R\&D data the patent data contains detailed information on each innovative invention, which is easier to distinguish the technical fields where the innovation activities are located in, as well as more accurately to identify green technology innovations. In addition, the patent data provides a series of information on the type of inventor, economic data, region, patent citation and transfer, so that research can examine the green technology innovation effect of environmental policy from many angles.

There are also some limitations in patent data that may bias the results of the study. One of the limitations is that the quality of patents is not easy to measure. Therefore current research usually uses two indicators: one is the number of patents cited, the more the number of citations, and the greater the value of patents (Popp, 2002); the other is the quantity of the patents families, which indicates the number of countries or regions where a patent applies for patent protection. Since patent applications and maintenance often require higher costs, inventors applying for patent protection in more regions generally reflect the higher commercial value of the patent (Dechezleprêtre et al., 2011; Aghion et al., 2016). The second limitation is the efficiency of patent conversion. It has been found that most of patents contribute lower commercial and practical value (Lanjouw et al. 1998). The third limitation is that the patent institution between different regions and different technology fields are various, which also brings some difficulties to the innovation comparison across regions and technologies.

\subsection{Questionnaire}

In order to overcome these limitations of patent data, some studies have begun to use corporate surveys to explore the specific impact of environmental policies on companies' green technology innovation activities. By using the data from the German Society for Innovation Survey (CIS) in 2009 Hornbach et al. (2012) found that different types of environmental policies encourage companies to innovate in different directions. Additionally, regulations provisions promote marginal effects of innovation in emissions management; however, the innovation subsidies are more effective in innovative research that stimulates carbon dioxide emissions reductions. Rogge and Schleich (2018) conducted a further questionnaire survey based on the 2009 CIS data and collected a total of 390 companies' 2014 questionnaires. Research indicates that innovation activities rely on clear policy signals, and the continuity and reliability of environmental policies are essential to promote green technology innovation. It can be seen that the advantages of the data based on questionnaire is more focused on green technology innovations related to practical applications, as well as provides information that is not available in many patent data. However, the challenges of the high cost of this type of survey, difficulties in designing the questionnaires, and the rare accesses to public survey, are all result in the difficulties data acquisition in this method.

China's related research uses R\&D investment or ecological total factor productivity to measure eco-technical innovation (eg Wang Bing et al., 2008; Jiang Fuxin et al., 2013). Both of these variables can hardly provide enough micro information to identify the technical areas in which innovation activities located. In contrast, the patent data is widely used in foreign researches that can more accurately target specific eco-technical innovations, including information on patent technology flows. In recent years, the use of patent data in China has gradually enriched. Qi Shaozhou et al. (2018) used the patent data of listed companies to prove the promotion of the sulfur dioxide emissions policy to the ecological technology innovation in the pilot areas; Wang Banban et al (2016) found the heterogeneity of the eco-technical effects of command-based and market-based environmental policies on different industries by conducting the patent data. Dong Zhiqing et al. (2019) studied the impact of environmental policy transfer on the ecotechnical patents of the two places. Although domestic and foreign researches both prefer using the metric of patent data, Chinese studies use the number of patent applications as a variable to measure innovation activities with no 
exceptions, while foreign studies are more likely to use the patent citations or patent families, which are believed presented the quality and value of the patent.

\section{Metrics of environmental policy intensity}

In order to assess the impact of environmental policies on ecological innovation activities, previous studies used a variety of indicators and estimation methods to measure the intensity of environmental policies.

\subsection{Polling Abatement Control Expenditures}

Early studies used Polling Abatement Control Expenditures (PACE) as a proxy variable to prove the positive impacts of environmental policy intensity in promoting eco-technical innovation (LanjouwandMody (1996), Jaffe and Palmer (1997), And Brunnermeierand Cohen (2003)). PACE indicators are also widely used in relevant research in China.

For instance, Jing Weimin and Zhang Wei (2014) used the industry's pollution treatment control expenditures rate as an indicator of environmental policy intensity, which proves that reasonable environmental regulation can stimulate the direction of technological progress and turn to ecology technological innovation. The advantages of the PACE indicator reflect the intensity of the policy itself and the implementation of the regulation to some extent regardless of some endogenous problems. When enterprises turn to ecological production and ecological technology innovation, their pollution control expenditures could be lower.

\subsection{Energy price}

Some studies use energy prices as a proxy variable for environmental policy. Price change usually consists of two factors: affecting by price fluctuations caused by supply and demand on one hand. Some studies found that ecological technology innovation activities are very sensitive to the changes in energy prices. Popp (2002) examined that the fluctuations of energy prices can significantly affect innovation in energy-saving technologies within five years. In addition, Dechezleprêtre et al. (2011) found that the impact of international oil prices on low-carbon patent innovations is almost undelayed. On the other hand, energy price differences are caused by energy tax rates in different countries or regions. Energy price also partly reflected the intensity of environmental policy in most international research (Aghion et al., 2016)

\subsection{The impact of a single policy}

An increasing number of research evaluates the ecological innovation effects of individual environmental policies by using quasi-natural experiment methods. Most of the evaluations of individual policies are likely to use quasi-natural experiments to better identify the causal relationship between environmental policies and ecological technology innovation. For example, the European Emissions Trading System (EU-ETS) (Schmidt et al., 2012), China's Air Pollution Prevention and Control Act (Li Shu, Chen Gang, 2013), and "Two Control Zones" (Jefferson et al., 2013) ), policy sulfur dioxide trading system (Tu Zhengge, Chen Renjun, 2015), clean production system (Han Chao, Hu Haoran, 2015) and so on.

\section{The effect of environmental policy on ecological technology innovation}

Hicks (1932) firstly proposed the theory of incentive effects of environmental policy on ecological innovation indicating that Induced Technical Change (ITC) believes that R\&D is a profit-driven investment behavior and therefore affected by the price of related factors. Environmental policy influences factor prices by "pricing" corporate emissions behaviors, thereby promoting eco-technical innovation (Newell et al., 1999) Choosing the right environmental policy is an important issue for policy makers, and yet existing research has not found an effective environmental policy tool. The methods of an order-based tool, a market-based tool or a voluntary tool, all possess advantages and limitations in inspiring ecological technology innovation.

\subsection{Command-and-control tools}

By setting clear emission reduction targets for companies the command tools take a significant impact on stimulating eco-technical innovation. Wang Banban and Qi Shaozhou (2016) took the energy intensity target of the "Eleventh FiveYear Plan" in 2006 as an order-oriented environmental policy, and found that compared with market-based tools, command-based tools are more innovative in energy-saving and emission-reducing technologies, and therefore have a stronger degree of innovation invention patent effects. Jefferson et al. (2012) found that stricter environmental regulations could help increase firm productivity in a research on acid rain and sulfur dioxide control zones.

However, some studies pointed out the limitations of some command-based tools. Firstly, the policy costs are comparatively high. Command-type tools do not take into account differences in technical capabilities and abatement costs between firms. Pereira and Vence (2015) believe that this "one size fits all" approach will create greater potential costs and is not conducive to the development of new technologies. 
Moreover, when the institutional standards of command-based tools are too high to be realized, the problems of economic rent-seeking and corruption will arise (Popp et al. 2012). Besides, the sustainability of policy effects is difficult to guarantee. Dekker et al. (2012) studied the impact of the Helsinki and Oslo agreements on the eco-technical innovations of signatory countries, which require signatories to significantly reduce sulfur dioxide (SO2) emissions. By using DID research method this study found that the promotion effect of the agreement on the eco-technical innovation among the signatory countries only appeared in the signing year and a short period before the signing. The article points out that the command-based tools could help companies innovate behaviors to meet policy requirements, but difficult to motivate continuous innovation.

\subsection{Market-based tools}

Command-type policies released a certain punitive effect on highly polluting enterprises, but no rewards for companies with lower than the pollution discharge standards. Therefore, market-based tools are comparatively more useful to promote sustained eco-technical innovations (Magat 1978, Milliman and Prince 1989, Fischer et al. 2003). However, some recent studies have shown that this approach by pricing environmental externalities alone may not be sufficient to motivate companies to make eco-technical innovations. The study of European Carbon Emissions Trading System (EU-ETS) compared companies inside and outside the EU-ETS using matching method and multiple difference method, found that although there was a significant increase in low-carbon technology patents after the second phase of EU-ETS, the EU carbon trading system plays a very limited role in low-carbon technology innovation by (Calel and Dechezleprêtre 2016). The results of Schmidt et al. (2012) presented a more negative research. This research is based on an evolutionary theoretical framework and author questionnaires. It found that in the first two stages of EUETS, the policy induced errors in technological innovation, leading to innovations tending to high-emission technologies. They believe that the EU carbon trading system should set a more stringent aggregate target.

\subsection{Voluntary tools}

Voluntary tools are based on mutual trust between the company and the government, which reduced the cost of direct government supervision, as well as enable enterprises greater flexibility and freedom to make decisions. Companies can adopt technology and $R \& D$ investment that is more suitable for their own situation so that to generate strong technical innovation incentives for enterprises. Carrión-Flores et al. (2013) studied the impact of the US Environmental Protection Agency's 33/50 program on corporate eco-innovation activities. The 33/50 program encourages large companies with high emissions to voluntary reduce emissions of 17 harmful pollutants. Based on the 1988 emissions, it reduced its pollutant emissions by 33\% in 1992 and increased its emission reductions to 50\% in 1995. In the view of short time, the number of eco-technical patents increased after the company voluntarily participated in the plan, but the number of patent applications will significantly decreased in five to nine years after the end of the 33/50 plan. In the long run, the number of applications for eco-tech patents for companies participating in the emission reduction plan is not as good as those not participating in the plan.

\section{Conclusion}

This paper summarizes the studies of impacts of different environmental policies on ecological technology innovation in developed and developing countries. For developed countries, a variety number of data makes its research content more extensive. However, research also shows that environmental policy does not necessarily promote ecological innovation, and more research on how to select and design environmental policies is needed in the future. For developing countries, taking China as an example, studies are more likely to uses panel data of industries or regions in examining the eco-technical innovation effects of environmental policies, but lack of micro-data based on the main body of innovation activities of enterprises. Rare research uses enterprise patent data as an innovation indicator and indicator is refer to the quantity of patents mainly. Although this index can reflect the output of R\&D activities to some extent, it is difficult to reflect the quality of innovation. Therefore, more attention needs to be paid to the impacts on the quality of innovation.

\section{References}

Acemoglu, D. 2002. "Directed Technical Change.” Review of Economic Studies. 69: 781-809.

Acemoglu, D., P. Aghion, L. Bursztyn, and D. Hemous. 2012. "The Environment and Directed Technical Change." American Economic Review. 102(1): 131-166.

Aghion, P., A. Dechezleprêtre, D. Hemous, R. Martin, and J. Van Reenen. 2016. "Carbon Taxes, Path Dependency and Directed Technical Change : Evidence from the Auto Industry.” Journal of Political Economy. 124: 1-51.

Al Mamum, M. K. Sohag, M. Shahbaz, and S. Hammoudeh. 2018. Financial Markets, Innovations and Cleaner Energy Production in OECD Countries.” Energy Economics. 72: 236-254. 
Allan, C., A.B. Jaffe, and I. Sin. 2013. "Diffusion of Green Technology: A Survey." International Review of Environmental and Resource Economics. 7: 1-33.

Anadon, L.D., E. Baker, V. Bosetti, and L.A. Reis. 2016. "Expert Views - and Disagreements about the Potential of Energy Technology R\&D." Climatic Change. 136: 677-69.

Angelucci, S., F.J. Hurtado-Albir and A. Volpe. 2018. “Supporting Global Initiatives on Climate Change: The EPO's "Y02-Y04S" Tagging Scheme." World Patent Information. 54: 585592.

Arrow, K.J. 1962. "The Economic Implications of Learning by Doing." Review of Economic Studies. 29: 155-173.

Blanc, E. and J. Reilly. 2017. "Approaches to Assessing Climate Change Impacts on Agriculture: An Overview of the Debate." Review of Environmental Economics and Policy. 11(2): 247-257.

Bollinger, B. and K. Gillingham. 2014. "Learning-by-Doing in Solar Photovoltaic Installations."Working Paper available at, accessed February 15, 2019. http://environment.yale.edu/gillingham/BollingerGillingham_SolarLBD.pdf

Bollinger, B. and K. Gillingham. 2012. "Peer Effects in the Diffusion of Solar Photovoltaic Panels." Marketing Science. 31(6): 900-912.

Brunnermeier, S. and M.A. Cohen. 2003. "Determinants of Environmental Innovation in US Manufacturing Industries." Journal of Environmental Economics and Management. 45: 278-293.

Brunnschweiler, C.N. 2010. "Finance for Renewable Energy: An Empirical Analysis of Eeveloping and Transition Economies." Environment and Development Economics. 15: 241-274.

Calel, R., and Dechezleprêtre, A. 2016. "Environmental Policy and Directed Technological Change: Evidence from the European Carbon Market." Review of Economics and Statistics. 98: 173-191.

Carrión-Flores, C. and R. Innes. 2010. "Environmental Innovation and Environmental Performance." Journal of Environmental Economics and Management. 59(1): 27-42.

Chakraborty, P. and C. Chatterjee. 2017. "Does Environmental Regulation Indirectly Induce Upstream Innovation? New Evidence from India." Research Policy. 46: 939-955.

Cohen, M.A. and A. Tubb. 2018. "The Impact of Environmental Regulation on Firm and Country Competitiveness: A Meta-analysis of the Porter Hypothesis." Journal of the Association of Environmental and Resource Economics. 5(2): 371-399.

Conti, C., M.L. Mancusi., F. Sanna-Randaccio, R. Sestini, and E. Verdolini. 2018. "Transition Towards a Green Economy in Europe: Innovation and Knowledge Integration in the Renewable Energy Sector." Research Policy. 47: 1996-2009.

Conway, D. A. Dechezleprêtre, I. Hascic and N. Johnstone. 2015. "Invention and Diffusion of Water Supply and Water Efficiency Technologies: Insights from a Global Patent Dataset." Water Economics and Policy. 1(4): 1550010.

Costantini, V., F. Crespi, and A. Palma. 2017. "Characterizing the Policy Mix and its Impact on Eco-innovation: A Patent Analysis of Energy-Efficient technologies.” Research Policy. 46: 799-819.

Dechezleprêtre, A. and M. Glachant. 2014. "Does Foreign Environmental Policy Influence Domestic Innovation? Evidence from the Wind Industry." Environmental and Resource Economics. 58 (3): 391-413.

Dechezleprêtre, A., M. Glachant, I. Hascic, N. Johnstone and Y. Ménière. 2011. "Invention and Transfer of Climate Change Mitigation Technologies on a Global Scale: A Study Drawing on Patent Data." Review of Environmental Economics and Policy. 5(1): 109-130.

Dechezleprêtre, A., R. Martin, and M. Mohnen, M. 2017. "Knowledge Spillovers from Clean and Dirty Technologies: A Patent Citation Analysis." Grantham Research Institute on Climate Change and the Environment Working Paper No. 135.

Fischer C., L. Preonas, and R. Newell R. 2017. "Environmental and Technology Policy Options in the Electricity Sector: Are We Deploying Too Many?" Journal of the Association of Environmental and Resource Economists. 4(4): 959-984.

Franco, C. and G. Marin. 2017. "The Effect of Within-Sector, Upstream and Downstream Environmental Taxes on Innovation and Productivity." Environmental and Resource Economics. 66: 261-291.

Fu, W., C. Li, J. Ondrich and D. Popp. 2018. "Technological Spillover Effects of State Renewable Energy Policy: Evidence from Patent Counts.” NBER Working Paper \#25390.

Jing Weimin, Zhanglu. 2014. "Environmental Regulation, Open-up strategy and Green Technology Progress of Chinese Industry.”Economic Research Journal.2014(09)

Gaddy, B.E., V. Sivaram, T.B. Jones and L. Wayman. 2017. "Venture Capital and Cleantech: The Wrong Model for Energy Innovation.” Energy Policy. 102: 385-395.

Gallager, K.S., L.D. Anadon, R. Kempener and C. Wilson. 2011. "Trends in Investments in Global Energy Research, Development, and Demonstration,” Wiley Interdisciplinary Reviews: Climate Change, 2(3), 373-396. 
Gray W.B. and R.J. Shadbegian. 1998. "Environmental Regulation, Investment Timing, and Technology Choice." Journal of Industrial Economics. 46(2): 235-256

Griliches, Z. 1990. "Patent Statistics as Economic Indicators: A Survey." Journal of Economic Literature. 28:(4): 16611707.

Hart, R. 2019. "To Everything There is a Season: Carbon Pricing, Research Subsidies, and the Transition to Fossil-Free Energy." Journal of the Association of Environmental and Resource Economists. 6(2): 135-175.

Heal, G. 2016. Endangered Economies: How the Neglect of Nature Threatens Our Prosperity.Columbia University Press, New York.

Hepburn, C. J. Pless and D. Popp. 2018. "Encouraging Innovation that Protects Environmental Systems: Five Policy Proposals." Review of Environmental Economics and Policy. 12(1): 154-169.Hicks J.R. 1932. The Theory of Wages Macmillan, London.

Horbach, J., C. Rammer and K. Rennings. 2012. "Determinants of Eco-innovations by Type of Environmental Impact — The Role of Regulatory Push/Pull, Technology Push and Market Pull.” Ecological Economics. 78: 112-122.

Horner, N., I. Azevedo, and D. Hounshell. 2013. "Effects of Government Incentives on Wind Innovation in the United States." Environmental Research Letters. 8: 1-7.

Howell, S.T. 2018. "Joint Ventures and Technology Adoption: A Chinese Industrial Policy That Backfired." Research Policy. 47: 1448-1462.

Kellogg, R. 2011. "Learning by Drilling: Interfirm Learning and Relationship Persistence in the Texas Oilpatch." Quarterly Journal of Economics. 126: 1961-2004.

Luo, S., M.E. Lovely, and D. Popp. 2017. "Intellectual Returnees as Drivers of Indigenous Innovation: Evidence from the Chinese Photovoltaic Industry." World Economy. 40(11): 2424-2454.

Mansfield E. 1996. Estimating social and private returns from innovations based on the Advanced Technology Program: Problems and opportunities. NIST GCR 99-780. Gaithersburg, MD: National Institute of Standards and Technology

Mansfield E. 1977. "Social and Private Rates of Return from Industrial Innovations." Quarterly Journal of Economics. 91: 221-40.

Marin, G. 2014. "Do eco-innovations harm productivity growth through crowding out? Results of an extended CDM model for Italy." Research Policy. 43: 301-317.

Milliman, S.R. and R. Prince. 1989. "Firm Incentives to Promote Technological Change in Pollution Control." Journal of Environmental Economics and Management. 17: 247-265.

National Science Board. 2018. "Research and Development: U.S. Trends and International Comparisons." Chapter 4 in Science and Engineering Indicators 2018. National Science Foundation, Arlington, VA.

Nemet, G.F. 2012a. "Inter-technology Knowledge Spillovers for Energy Technologies.” Energy Economics. 34: 12591270.

Nemet, G.F., 2012b. "Knowledge Spillovers from Learning by Doing in Wind Power." Journal of Policy Analysis and Management. 31(3): 600-621.

Nemet, G.F., V. Zipperer and M. Krause. 2018. "The Valley of Death, the Technology Pork Barrel, and Public Support for Large Demonstration Projects.” Energy Policy. 119: 154167.

Newell, R. A.B. Jaffe and R. Stavins. 1999. "The Induced Innovation Hypothesis and Energy-Saving Technological Change.” The Quarterly Journal of Economics. 114(3), 941-975.

Peters, M., M. Schneider, T. Griesshaber and V.H. Hoffman. 2012. "The impact of technologypush and demand-pull policies on technical change-Does the locus of policies matter?" Research Policy. 41 (8):1296-1308.

Popp, D. 2017. "From Science to Technology: The Value of Knowledge From Different Energy Research Institutions." Research Policy. 46(9): 1580-1594.

Popp, D. 2016. "Economic Analysis of Scientific Publications and Implications for Energy Research and Development." Nature Energy. 1(4), 1-8, DOI: 10.1038/nenergy.2016.20.

Popp, D. 2011. "International Technology Transfer, Climate Change, and the Clean Development Mechanism." Review of Environmental Economics and Policy. 5(1): 131-152.

Popp, D. 2006. "International Innovation and Diffusion of Air Pollution Control Technologies: The Effects of NO X and SO 2 Regulation in the U.S., Japan, and Germany." Journal of Environmental Economics and Management. 51(1): 46-71.

Popp, D. 2004. "ENTICE: Endogenous Technological Change in the DICE Model of Global Warming." Journal of Environmental Economics and Management. 48(1): 742-768.

Popp, D. 2002. "Induced Innovation and Energy Prices.” American Economic Review. 92(1): 160180.

Popp, D., N. Santen, K. Fisher-Vanden and M. Webster. 2013 "Technology Variation vs. R\&D Uncertainty: What Matters Most for Energy Patent Success?” Resources and Energy Economics. 35(4): 505-533. 
Powell, W.W., K.W. Koput and L. Smith-Derr. 1996. "International Collaboration and the Locus of Innovation: Networks of Learning in Biotechnology." Administrative Science Quarterly. 41(1): 116-145.

Reichardt, K. and K. Rogge. 2016. "How the Policy Mix Impacts Innovation: Findings from Company Case Studies on Offshore Wind in Germany." Environmental Innovation and Societal Transitions. 18: 62-81.

Rogge, K.S. and J. Schleich. 2018. "Do Policy Mix Characteristics Matter for Low-carbon Innovation? A Survey-based Exploration of Renewable Power Generation Technologies in Germany." Research Policy. 47: 1639-1654.

Rosenberg, N. 1982. Inside the Black Box: Technology and Economics. Cambridge University Press, Cambridge, UK.

Sanchez, D.L., Sivaram, V. 2017. "Saving Innovative Climate and Energy Research: Four Recommendations for Mission Innovation.” Energy Research and Social Science. 29: 123126.

Sanyal, P. and S. Ghosh. 2013. "Product Market Competition and Upstream Innovation: Evidence from the U.S. Electricity Market Deregulation.” Review of Economics and Statistics 95(1): 237-254.

Stucki, T. and M. Woerter. 2017. "Green Inventions: Is Wait-and-see a Reasonable Option?" The Energy Journal. 38(4): 43-71.

Sunstein, C.R. 2007. "Of Montreal and Kyoto: A Tale of Two Protocols.” Harvard. Environmental Law Review. 31: 166.

Thompson, P. 2012. "The Relationship between Unit Cost and Cumulative Quantity and the Evidence for Organizational Learning-by-Doing." Journal of Economic Perspectives. 26(3): 203-224.

Verdolini, E., L.D. Anadón, E. Baker, V. Bosetti and L.A. Reis. 2018. "Future Prospects for Energy Technologies: Insights from Expert Elicitations." Review of Environmental Economics and Policy. 12(1): 133-153.

Verdolini, E. and M. Galeotti. 2011. "At Home and Abroad: An Empirical Analysis of Innovation and Diffusion in Energy Technologies." Journal of Environmental Economics and Management. 61: 119-134.

Veugelers, R. 2012. "Which Policy Instruments to Induce Clean Innovating?” Research Policy.41: 1770-1778.

Vollebergh, H.R.J. and E. van der Werf. 2014. "The Role of Standards in Eco-Innovation: Lessons for Policymakers." Review of Environmental Economics and Policy. 8: 230-248.

Vona, F., G. Marin and D. Consoli. forthcoming. "Measures, Drivers and Effects of Green Employment. Evidence from US local labor markets, 2006-2014." forthcoming in Journal of Economic Geography.

Vona, F., G. Marin, D. Consoli and D. Popp. 2018. "Environmental Regulation and Green Skills:an empirical exploration." Journal of the Association of Environmental and Resource Economists. 5(4): 713-753.

Weyant, J. 2011. "Accelerating the Development and Diffusion of New Energy Technologies:Beyond the 'Valley of Death." Energy Economics. 33: 674-682.

Wuchty, S., B.F. Jones, and B Uzzi. 2007. "The Increasing Dominance of Teams in Production of Knowledge." Science 316: 1036-1039. 